\title{
FLORA MALESIANA PRECURSOR FOR THE TREATMENT OF MORACEAE 1: THE MAIN SUBDIVISION OF FICUS: THE SUBGENERA
}

\author{
C.C. BERG \\ The Norwegian Arboretum/Botanical Institute, University of Bergen, \\ N-5259 Hjellestad, Norway
}

SUMMARY

\begin{abstract}
A revised subgeneric subdivision of Ficus is proposed. Some important characters on which this subdivision is based are discussed, a key to the subgenera is presented. Distribution and relationships of the subgenera are briefly discussed.
\end{abstract}

Key words: Ficus subg. Ficus, subg. Pharmacosycea, subg. Sycidium, subg. Sycomorus, subg. Synoecia, subg. Urostigma, worldwide.

\section{GENERAL INTRODUCTION}

More than 30 years ago Dr. E.J.H. Corner submitted a manuscript comprising the treatments of Ficus L. and most of the smaller genera of Moraceae for Flora Malesiana. Treatments of Artocarpus J. Forst. \& G. Forst. and allied genera were submitted by Dr. F.M. Jarrett about 10 years later. I have undertaken the task to update the manuscripts. The task proved to be far more extensive than including recent collections and new data from recent publications (as Corner, 1969, 1970a, b, 1972, 1975; Go, 1998; Kochummen, 1998; Weiblen in Laman \& Weiblen, 1998). The revision of the manuscripts is largely based on material at L. Some collections, mainly types, have been borrowed from other herbaria. The re-examination of material led to changes in circumscriptions of species, as by including varieties, sometimes by uniting species or re-instating species. In order to make the infrageneric subdivision more transparent, the number of entities is reduced. In the descriptions of both the infrageneric entities and the species the accent is moved from flower and fruit characters to vegetative ones. Changes made reconstruction of keys necessary. Checking upon nomenclature and cited literature has been done to a very limited extent. Part of the work carried out will be presented in a number of precursory papers, which will include new taxa and combinations, altered familial and generic subdivisions, annotated lists of accepted species, and reconstructed keys, with reference to the major precursory studies by Corner (1960a-f, 1961, 1962a, b, 1965). The intended sequence of the successive precursors is: Ficus (2) subg. Pharmacosycea (Miq.) Miq., (3) subg. Ficus, (4) subg. Synoecia (Miq.) Miq., (5) subg. Sycidium (Miq.) Mildbr. \& Burret, (6) subg. Sycomorus (Gasp.) Miq., (7) subg. Urostigma (Gasp.) Miq., (8) the smaller genera of Moraceae, and (9) Artocarpus. 


\section{SUBDIVISION OF FICUS}

The first and very simple subdivision of Ficus was designed by Thunberg (1786) and adopted by Vahl (1805) and was based on the leaf shape - lobate versus entire -, the former group comprising only $F$. carica. It was succeeded by numerous other, more elaborate, subdivisions, on which the decision by Gasparrini $(1844,1845)$ to split the genus into many genera had a strong influence. These genera, such as Galoglychia, Sycomorus, and Urostigma, were largely based on floral characters. Miquel initially adopted Gasparrini's concept and extended the number of genera to also include Pharmacosycea (Miquel, 1847), Pogonotrophe (Miquel, 1847) and Synoecia (Miquel, 1848). In a worldwide survey of the genus (1867), he finally united all these genera into Ficus, reducing many of them to infrageneric entities. It took nearly a century before a more modern classification of the whole genus was presented, namely the one by Corner $(1958,1960 a-f, 1961,1962 b$, summarized in 1965). Various characters of staminate and pistillate flowers and of fruitlets and some leaf anatomical characters, like the distribution of cystoliths, played an important role in the construction of Corner's classification, albeit with some neglect of macromorphological characters, in particular of vegetative parts. The classification of Corner has been challenged by Ramirez and Berg. Ramirez (1977) has suggested changes that better reflect the understanding of the fig wasp taxonomy and classification. While Berg $(1989,1990,1998)$ has suggested changes based on his work on African members of the genus. The current study on Malesian species created a possibility to check more closely upon Corner's classification. This has led to the here proposed classification of the genus. It is primarily based on morphological criteria and takes into account various comments by Corner (1960e, 1967 ) on the classification he proposed. Corner (1960e: 3) suggested to consider a separate subgenus combining the sections Kalosyce and Rhizocladus and to include the sections Adenosperma, Neomorphe, and Sycocarpus, but also the series Prostratae and Pungentes (of sect. Sycidium) in subgenus Sycomorus, if unifying characters could be found (1967: 51). The unifying character proved to be the presence of 2 bracteoles subtending the staminate flowers.

Corner recognized three monoecious subgenera, Pharmacosycea, Sycomorus, and Urostigma, and a single subgenus for all (gyno)dioecious species, Ficus, with numerous sections, subsections, series, and subseries.

In the presently proposed subdivision, the genus comprises six subgenera: Pharmacosycea and Urostigma with only monoecious species, Ficus, Sycidium, and Synoecia with only (gyno)dioecious species, and Sycomorus with (gyno)dioecious and (few) monoecious species. This subdivision is in the outlines presented here supported by the analyses by Weiblen (2000), which were partly based on molecular data. The exception is the problem in subg. Pharmacosycea, as indicated below.

Further subdivisions of the subgenera into sections and subsections will be presented in precursory papers to publish new species. 


\section{SUBGENERA OF FICUS}

Subgenus Pharmacosycea (Miq.) Miq. (1867) 299

Terrestrial trees or shrubs without adventitious roots (rarely otherwise), monoecious. Leaves usually in spirals; lamina symmetric, mostly coriaceous, the margin mostly entire; waxy glands mostly in the axils of the basal lateral veins beneath, sometimes absent; stipules fully amplexicaul. Figs axillary, sometimes just below the leaves, rarely cauliflorous; basal bracts 3, verticillate; lateral bracts absent, occasionally present; ostiole with interlocking bracts, few upper ones visible; interfloral bracts usually present; internal hairs mostly absent. Staminate flowers scattered among the pistillate ones; stamens 1 or 2; pistillode sometimes present. Stigmas usually 2, subulate and not conspicuously papillate. Fruits achenes.

Distribution - From Africa to Australia and the Pacific and in tropical America; c. 80 species.

Pollinators - Species of Dolichoris (sect. Oreosycea) and Tetrapus (sect. Pharmacosycea) (Berg \& Wiebes, 1992; Wiebes, 1994, 1995).

Delimitation - The delimitation as proposed by Corner (1960a) is adopted unchanged.

Note - An aberrant life form has been described for the Neotropical F. crassiuscula Standl. by Daniels \& Lawton (1991). The species is hemi-epiphytic with viny saplings.

\section{Subgenus Urostigma (Gasp.) Miq. (1867) 285}

Hemi-epiphytic, hemi-epilithic, or less commonly terrestrial trees with aerial adventitious roots which often (or always?) replace the primary root-system, monoecious. Leaves mostly in spirals, sometimes subopposite; lamina symmetric, mostly coriaceous, the margin mostly entire; a single waxy gland at the base of the midrib beneath; stipules fully amplexicaul. Figs axillary or just below the leaves, sometimes ramiflorous or cauliflorous; basal bracts 2 or 3, verticillate; lateral bracts absent; ostiole with interlocking bracts and the ostiole circular with 2 or 3 bracts visible or the upper ostiolar bracts descending and the aperture slit-shaped or triradiate; interfloral bracts usually present; internal hairs (bristles) sometimes present. Staminate flowers scattered among the pistillate ones or sometimes near the ostiole; stamen 1 (or 2); pistillode usually absent. Stigmas mostly 1 , sometimes 2 , filiform, mostly conspicuously papillate. Fruits achenes or \pm drupaceous.

Distribution - From Africa to Australia and the Pacific, and in tropical America; c. 280 species.

Pollinators - Species of Agaon, Alfonsiella, Allotriozoon, Courtella, Deilagaon, Elisabethiella, Eupristina (subgenera Eupristina and Parapristina), Nigriella, Paragaon, Pegoscapus, Platyscapa, Pleistodontes, Watersoniella, largely associated with entities at the section or subsection level (Wiebes, 1992, 1994, 1995).

Delimitation - The delimitation as proposed by Corner (1960b) is adopted unchanged. 


\section{Subgenus Ficus}

Terrestrial trees or shrubs, rarely holo-epiphytic, with adventitious roots only on creeping stems, dioecious. Leaves in spirals; lamina symmetric, often subcoriaceous to chartaceous, the margin often dentate (or lobate); waxy glands mostly in the axils of the basal lateral veins beneath, also (or only) in furcations or on the nodes of leafy twigs; stipules fully amplexicaul, sometimes semi-amplexicaul. Figs in the leaf axils or just below the leaves; basal bracts 3, verticillate; ostiole relatively large, mostly with more than 3 upper ostiolar bracts visible; internal bracts absent; internal bristles mostly present. Tepals often hairy. Staminate flowers near the ostiole or scattered among the pistillate ones; stamens 1-3(-4); pistillode usually absent. Stigmas of long-styled flowers often 2, subulate, without conspicuous papillae. Fruits achenes.

Distribution - From eastern Malesia to north-eastern Africa and the Mediterranean; c. 60 species.

Pollinators - Species of Blastophaga (Blastophaga and Valisia) (Wiebes, 1994); the two subgenera of wasps associated with the two sections of subg. Ficus.

Delimitation - In the present concept the following subdivisions proposed by Corner (see 1965) are included: subg. Ficus sect. Ficus, except for subsect. Ficus ser. Pseudopalmae Corner, ser. Rivulares Corner (1960c) 418, and ser. Sinosyceae Corner (1960c) 418.

Subgenus Synoecia (Miq.) Miq. (1867) 289

Root-climbers with short adventitious roots on climbing stems, dioecious. Leaves distichous, rarely in lax spirals, those of the climbing stems and branches (bathyphylls) different from those of the non-climbing (and fertile) branches (acrophylls); lamina symmetric (acrophylls) or asymmetric (bathyphylls), coriaceous (acrophylls) or subcoriaceous to chartaceous (bathyphylls), the margin entire; waxy glands in the axils of the basal lateral veins beneath, rarely on the nodes of leafy twigs. Figs axillary or just below the leaves, sometimes ramiflorous or cauliflorous; basal bracts 3 , verticillate; interfloral bracts absent; ostiole relatively small, with few (3) upper ostiolar bracts visible; internal hairs mostly present. Tepals glabrous (rarely hairy). Staminate flowers near the ostiole or scattered among the pistillate ones; stamens 1 or 2 (or 3); pistillode usually absent. Stigmas of long-styled flowers often 2, subulate. Fruits achenes.

Distribution - From the Solomon Islands and Australia to Japan and Sri Lanka; c. 75 species.

Pollinators - Species of Wiebesia (Wiebes, 1994).

Delimitation - In the present concept the following subdivisions proposed by Corner (see 1965) are included: subg. Ficus sect. Kalosyce (Miq.) Corner (1960e) 3 and subg. Ficus sect. Rhizocladus Endl. (1850) 34.

Note - Ficus laevis Blume is a root-climber without leaf dimorphy, the leaves are arranged in lax spirals, and waxy glands occur on the nodes of leafy twigs. Hairs are sometimes present on tepals of F. pubigera (Miq.) Miq. 
Subgenus Sycidium (Miq.) Mildbr. \& Burret (1912) 174

Terrestrial shrubs or trees with adventitious roots only on creeping stems or climbers, creepers, hemi-epiphytes or subepiphytic (?) with adventitious aerial roots, dioecious. Leaves in spirals, distichous, subopposite, or subverticillate; lamina often chartaceous to subcoriaceous, mostly asymmetric, the margin often dentate (to lobate); waxy glands on the lower surface of the lamina, in the axils of both main basal lateral veins, or only in one of them, or sometimes a third in the axil of a lesser basal lateral vein, or sometimes both occur largely on the midrib and then occasionally fused, or sometimes (smaller) ones in the axils of other lateral veins; stipules semi-amplexicaul to lateral or less frequently fully amplexicaul. Figs in the leaf axils, just below the leaves, ramiflorous, cauliflorous, or sometimes flagelliflorous; peduncular bracts usually scattered on the peduncle; lateral bracts frequently present; interfloral bracts absent; ostiole usually with numerous upper bracts visible; internal hairs usually present. Staminate flowers near the ostiole; stamens 1 (or 2); pistillode (or pistil) always present. Stigma (also of long-styled flower) $1, \pm$ trunctate. Fruits achenes or drupelets.

Distribution - From Africa to Australia and the Pacific; c. 110 species.

Pollinators - Species of Kradibia (sect. Sycidium) and Liporropalum (sect. Palaeomorphe) (Wiebes, 1994).

Delimitation - In the present concept the following subdivisions proposed by Corner (see 1965) are included: subg. Ficus sect. Palaeomorphe (King) Corner (1960d) 446, subg. Ficus subsect. Ficus ser. Sinosyceae Corner (1960a) 418, subg. Ficus sect. Sinosycidium Corner (1960e) 24, and subg. Ficus sect. Sycidium Miq. (1848) 228, except for subsect. Sycidium ser. Prostratae Corner (1960d) 444 and ser. Pungentes Corner (1960d) 444.

\section{Subgenus Sycomorus (Gasp.) Miq. (1867) 295}

Terrestrial trees or shrubs, with adventitious roots only on creeping branches, dioecious or monoecious. Leaves in spirals, subopposite, or distichous; lamina symmetric or asymmetric, coriaceous or chartaceous to subcoriaceous, the margin often dentate; waxy glands in the axils of the basal lateral veins, also or only in the axils of other lateral veins, often also in furcation of veins beneath, or also on the nodes of leafy twigs; stipules fully amplexicaul. Figs axillary, just below the leaves, ramiflorous, cauliflorous and/or flagelliflorous; basal bracts if distinct, then mostly 3 and mostly verticillate; interfloral bracts absent; ostiole often large with numerous upper bracts visible; internal hairs usually present. Staminate flowers near the ostiole, nearly always subtended by 2 bracteoles; stamens 2; pistillode usually absent. Stigma (also of long-styled flowers) 1 , usually \pm truncate. Fruits achenes.

Distribution - From Africa to the Pacific; c. 140 species.

Pollinators - Species of Ceratosolen (subgenera Ceratosolen, Rothropus, and Strepitus) (Wiebes, 1994).

Delimitation - In the present concept the following subdivisions proposed by Corner (see 1965) are included: subg. Ficus sect. Adenosperma Corner (1958) 43, subg. Ficus sect. Neomorphe King (1887) 1, subg. Ficus sect. Sycocarpus Miq. (1844) 33, subg. Ficus sect. Ficus subsect. Ficus ser. Pseudopalmae Corner (1960c) 418 and ser. 
Rivulares Corner (1960c) 418, and subg. Ficus sect. Sycidium subsect. Sycidium ser. Prostratae Corner (1960d) 444 and ser. Pungentes Corner (1960d) 444.

Note - The characteristic bracteoles subtending the staminate flowers are not found in a few species, all with very small fig receptacles, about $5 \mathrm{~mm}$ in diameter when dry; the absence of the bracteoles appears to be related to the small size of the receptacle.

\section{MAJOR DIFFERENTIATING CHARACTERS}

Some of the characters of importance for the subdivision of the genus are discussed, more or less generalizing, as not all unusual and transitional states are mentioned.

\section{Monoecy-dioecy}

The monoecious species have figs (syconia) containing staminate flowers and pistillate flowers with different style-lengths. Long-styled flowers and short-styled flowers can be distinguished, but the heterostyly is imperfect as intermediates occur. All pistillate flowers can produce seeds. At the receptive state (anthesis of the pistillate flowers), the ovaries are arranged in more than one row; the long-styled flowers being mostly sessile and the short-styled flowers pedicellate. In the dioecious species, plants produce either figs with staminate flowers and only short-styled pistillate flowers or figs with only long-styled flowers, and often also neuter flowers, substituting staminate flowers. Heterostyly is perfect in these species and the short-styled flowers do normally not produce seeds, in spite of the fact that the ovules of these flowers are morphologically normal. The ovaries, in the receptive state, are more or less clearly arranged in one row, the differentiation of the pedicel length taking place after anthesis.

The study by Weiblen (2000) indicates that the two groups of monoecious species in the largely dioecious subg. Sycomorus arose as independent reversals to monoecy.

\section{Adventitious roots}

The ability to produce aerial adventitious roots is the basis for some of the life and growth forms in Ficus: hemi-epiphytes and some types of climbers. Adventitious roots which can produce large systems of roots that can anastomose are characteristic for subg. Urostigma. These extensive root systems often, or always?, replace the primary root system in early stages of development (cf. Prósperi, 1998) and allows the plants to be hemi-epiphytic or hemi-epilithic. In species or individuals, which are terrestrial the aerial roots form pillar- or stilt-roots. Less powerful aerial root systems, characteristic for subg. Sycidium sect. Palaeomorphe, achieve less pronounced types of hemi-epiphytism or subepiphytism in connection with a climbing habit. Short aerial roots on trailing or climbing stems and branches are characteristic for subg. Synoecia. In other groups, such as subg. Ficus, subg. Sycidium sect. Sycidium, and subg. Sycomorus adventitious roots can be formed on creeping stems or branches.

\section{Stipules}

The stipules are mostly fully amplexicaul, leaving annular scars. Lateral or semiamplicaul stipules frequently occur in subg. Sycidium; in some of its species both fully and partly amplexicaul stipules can be found. Lateral to semi-amplexicaul stipules are found in subg. Ficus on the stem parts with long internodes of the group of mainly frutescent species with 'Terminalia-branching' in subg. Ficus (ser. Podosyceae, see Corner, 1960c: 418). 


\section{Position of figs}

In most species the figs are only born in the leaf axils, mostly in pairs. In several of these species the figs can also be found just below the leaves, in particular if the growth of branches is not continuous but rhythmic (or seasonal). In many species figs are ramiflorous, being produced on leafless short-shoots, called spurs, which often already develop in the leaf axils and continue to produce figs on the older wood. Such short-shoots often bear more than two figs simultaneously.

Cauliflory is found in most subgenera, but most frequently and prominently in subg. Sycidum and subg. Sycomorus. In several species of the African section Galoglychia of subg. Urostigma, the figs are born on the main branches and the trunk on peg-like (unbranched) leafless short-shoots, in some species up to $10 \mathrm{~cm}$ long. Cauliflory on unbranched or branched leafless branchlets with short internodes occurs in species of the subgenera Sycidium, Sycomorus, and Synoecia. Figs born on branched leafless branches with long internodes are found in subg. Sycidium, but more frequently in Sycomorus, and rarely in Pharmacosycea (sect. Oreosycea). Such branches departing from the base of the trunk can be long and stolon-like (flagellifory).

Bracts

Various types of bracts can be distinguished:

1) Subtending bracts probably representing prophylls. They are found in particular in subg. Sycidium, but are often small and inconspicuous. They are large and free in (sub)sect. Malvanthera or small to large and fused, forming a calyptrate structure enclosing young figs, in many species of other sections of subg. Urostigma.

2) Peduncular bracts, up to three (or four) scattered on the peduncle instead of forming a whorl subtending the receptacle. They are commonly found in subg. Sycidium, and sometimes in subg. Pharmacosycea (sect. Oreosycea) and subg. Sycomorus (sect. Adenosperma).

3) Basal bracts, three or two arranged in a whorl at the base of the receptacle, which can be stipitate!, are found in all subgenera.

4) Lateral bracts, few or numerous on the outer surface of the receptacle. They are found in many species of subg. Sycidium and subg. Sycomorus, and occasionally in subg. Pharmacosycea.

5) Apical bracts, which are lateral bracts arranged around the ostiole.

6) Ostiolar bracts, numerous, in the ostiole. The upper ones can be numerous in subg. Sycidium and subg. Sycomorus and may point upwards. In most subgenera, there are three, or two horizontal, more or less semicircular and imbricate bracts closing the entrance. In Urostigma sect. Galoglychia and (sub)sect. Malvanthera the two or three upper ones are long and descending and make the entrance slit-shaped or triradiate. In other groups without descending ostiolar bracts, the bracts are interlocking with the lower bracts often descending.

7) Interfloral bracts, few or numerous among the flowers, or sometimes on the pedicels. They are found in (almost?) all species of subg. Pharmacosycea and subg. Urostigma. In subg. Pharmacosycea they are often found on the pedicels or even may be indistinguishable from the tepals, and, thus, seemingly lacking.

8) Bracteoles, two, or three, subtending and often also enclosing the staminate flowers. The are found in almost all species of subg. Sycomorus, and are absent in all other subgenera. 
In some species of subg. Sycidium and subg. Sycomorus numerous bracts occur from the base of the receptacle or the base of the peduncle up to the ostiole; the distinction between peduncular, basal, lateral, and apical bracts can then not be made.

In many species of the subgenera lacking interfloral bracts, internal hairs are found; they are often bristle-like. Internal hairs occur in some species of Urostigma in addition to interfloral bracts.

\section{Stigmas}

Two stigmas are found in most species of subg. Pharmacosycea and, at least, in the long-styled flowers of subg. Ficus and subg. Synoecia, in which the stigmas of the short-styled flowers are mostly truncate. The two stigmas are subulate, often unequal in length, and not conspicuously papillate. In subg. Urostigma, the style mostly bears a single papillate stigmatic arm. Subgenus Sycidium and subg. Sycomorus differ from the other subgenera in the absence of subulate stigmas. The styles pass into clavate, infundibuliform, or 'flame-shaped' stigmatic parts.

\section{Waxy glands}

In almost all species of Ficus, small glandular spots with a waxy surface are found. A single gland at the base of the midrib of the lamina beneath is characteristic for subg. Urostigma. Waxy glands are also found in this position in some species of subg. Sycidium, in which, like in all other subgenera, the waxy glands generally occur in the axils of the basal lateral veins beneath, in both or unilaterally. Additional smaller glands are often found in the axils of other lateral veins or also in furcations of veins. Large glands are found in the furcations of the midrib of F. deltoidea (subg. Ficus). In subg. Sycomorus sect. Sycocarpus, the waxy glands are usually only found in the axils of lateral veins in the middle of the lamina. In some species, the waxy glands are not always clearly present. They are lacking in a small group of species of subg. Pharmacosycea and probably in some species of subg. Ficus and subg. Sycomorus. In many species of subg. Sycomorus, in some species of subg. Ficus, and in one species of subg. Synoecia, pairs of waxy glands occur on the nodes of branches near the base of the petiole.

\section{DISTRIBUTION}

The six subgenera have pairwise more or less similar patterns of distribution. Subgenus Pharmacosycea and subg. Urostigma range in the Old World from the Pacific to West Africa and are both with a distinct section represented in the Neotropics. Both Neotropical sections show morphological similarities to Asian representatives of the subgenera, but lack morphological links to African groups of the two subgenera, and have their main centres of distribution in the northern Andean region and Central America. Subgenus Urostigma is clearly distinct from subg. Pharmacosycea in the presence of quite distinct and/or speciose groups confined to the African region (sect. Galoglychia) or centred in Australia ((sub)sect. Malvanthera). Subgenus Pharmacosycea is distinct by a speciose group almost confined to New Caledonia. Both subg. Sycidium and subg. Sycomorus range from the Pacific to West Africa. They show similarities in the 
phytogeographic centres of their subgroups. Subgenus Ficus and subg. Synoecia are more restricted in their distribution, hardly extending outside the Malesian region and the Asian mainland.

\section{RELATIONSHIPS}

The similarities in the distribution might reflect relationships between the pairs of subgenera, or, at least, speciation events in the same epoch of the evolution of the genus. The subgenera Pharmacosycea and Urostigma might be less closely related than one may assume on the basis of shared monoecy and characters associated with that state. Molecular studies have revealed the possibility that the Neotropical section of subg. Pharmacosycea is the sister group of the rest of the genus (Herre et al. 1996; Weiblen, 2000). Such a position is, however, not supported by the morphological differentiation in the genus. On the other hand some morphological features and irregularities in subg. Pharmacosycea could indicate closer affinities to the (gyno)dioecious subgenera than to subg. Urostigma. Subgenera Ficus and Synoecia are clearly related as with regard to the features of the fig, verticillate basal bracts and absence of lateral bracts, and the shape of the stigmas of the long-styled flowers. They could be argued into a single subgenus. Although the ranges of variation of floral characters, colour and indumentum of tepals and the shape of anthers, are clearly different, the difference in habit is the main and most evident reason to keep them separate at the subgenus level. Another reason is more practical, namely to keep sufficient lower infrageneric ranks available. The use of the difference in habit as the main argument to separate the two subgenera, makes recognition of two sections in Sycidium, sect. Sycidium and sect. Palaeomorphe, somewhat questionable, as the difference in habit is also for these groups the major differentiating character. A reason to keep them together in the same subgenus is to establish equivalence between subg. Sycidium and subg. Sycomorus (Table 1).

Table 1. Differences between the two pairs of dioecious subgenera.

\begin{tabular}{|c|c|c|}
\hline & Ficus + Synoecia & Sycidium + Sycomorus \\
\hline 1. Stigmas of the two morphs & clearly different & not clearly different \\
\hline 2. Staminate flowers & $\begin{array}{l}\text { scattered among the } \\
\text { pistillate ones or near } \\
\text { the ostiole }\end{array}$ & near the ostiole \\
\hline 3. Lateral bracts & $\begin{array}{l}\text { absent, basal bracts } 3 \text {, } \\
\text { verticillate }\end{array}$ & $\begin{array}{l}\text { often present, basal bracts often } \\
\text { not } 3 \text {, often not verticillate }\end{array}$ \\
\hline 4. Figs & mostly axillary & often cauliflorous \\
\hline 5. Leaves & in spirals or distichous & $\begin{array}{l}\text { subopposite, subverticillate, } \\
\text { distichous, or in spirals }\end{array}$ \\
\hline 6. Distribution & Malesia +Asian mainland & Africa to Pacific \\
\hline
\end{tabular}

In the character states of 2,3, and 4, Ficus and Synoecia match those of the two monoecious subgenera. 


\section{POLLINATORS}

The classification proposed here is at least at the level of subgenera, but also at the levels of sections and/or subsections, largely in accordance with the taxonomy of the group of pollinating fig wasps (Agaoninae). There are few cases, that the wasp genus does not match the subgenus or section of Ficus.

The mismatches known (Wiebes, 1994) are: F. asperiuscula Kunth \& C.D. Bouché and F. complexa Corner (subg. Sycidium sect. Sycidium) Ceratosolen instead of Kradibia; F. primaria Corner (subg. Sycidium sect. Sycidium) Wiebesia instead of Kradibia; F.montana Burm.f. (subg. Sycidium sect. Sycidium) Liporrhopalum instead of Kradibia; F. pritchhardii Seem. with Ceratosolen subg. Ceratosolen, found in the majority of the species of subg. Sycomorus instead of subg. Strepitus, known from the two other species of the same subdivision of monoecious species, $F$. itoana Diels and F. microdictya Diels; these may be caused by misidentifications of plant material.

\section{KEY TO THE SUBGENERA OF FICUS}

1a. Plants monoecious, the figs containing staminate flowers and pistillate flowers with different style lengths; leaves usually in spirals, rarely subdistichous or subopposite; lamina rarely scabrous $\ldots \ldots \ldots \ldots \ldots \ldots \ldots \ldots \ldots \ldots \ldots \ldots \ldots \ldots \ldots \ldots \ldots$

b. Plants (gyno)dioecious, the figs containing either staminate flowers and pistillate flowers with short styles or only pistillate flowers with long styles (or also neuter flowers); leaves often distichous or (sub)opposite . . . . . . . . . . 4

2a. Figs without interfloral bracts; staminate flowers near the ostiole and subtended and enveloped by 2 bracteoles . . . . . . . . . . . Subg. Sycomorus p.p.

b. Figs with interfloral bracts; staminate flowers mostly scattered among the pistillate

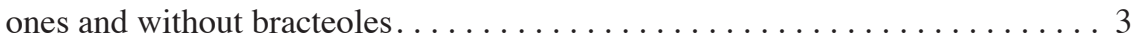

3a. Waxy gland one, at the base of the midrib beneath; aerial adventitious roots usually present; stamen usually 1 ; stigmas usually 1 , usually distinctly papillate. . . . . .

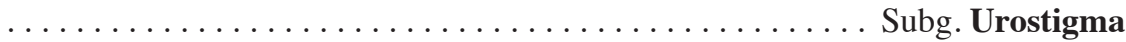

b. Waxy glands two, in the axils of the basal lateral veins beneath or absent; aerial roots absent; stamens 1 or 2 ; stigma usually 2 , without distinct papillae . . . . . . $\ldots \ldots \ldots \ldots \ldots \ldots \ldots \ldots \ldots \ldots \ldots \ldots \ldots \ldots \ldots$ Subg. Pharmacosycea

4a. Stipules often not fully amplexicaul; lamina often asymmetric; bracts mostly scattered on the peduncle and not 3 in a whorl as basal bracts; pistillode (or pistil) always present in the staminate flower . . . . . . . . . Subg. Sycidium

b. Stipules nearly always fully amplexicaul; lamina symmetric or asymmetric; basal bracts 3 , in a whorl, sometimes basal and lateral bracts not distinguishable; pistil-

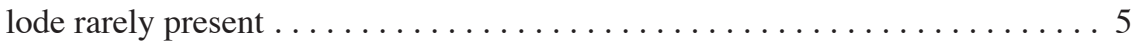

5a. Root-climbers usually with pronounced leaf dimorphy . . . . . . Subg. Synoecia

b. Trees or shrubs without aerial roots and leaf dimorphy $\ldots \ldots \ldots \ldots \ldots 6$

6a. Staminate flowers near the ostiole and mostly subtended by bracteoles; figs often cauliflorous or flagelliflorous; lateral bracts often present; lamina often asymmetric; in dried material the nodes of leafy twigs often thicker than the internodes and the lamina with lead-coloured spots above . . . . . . . Subg. Sycomorus p.p. 
b. Staminate flowers scattered among the pistillate ones or near the ostiole, not subtended by bracteoles; figs mostly axillary or just below the leaves; lamina symmetric; in dried material the nodes of leafy twigs almost as thick as the internodes and lead-coloured spots absent on the lamina above. . . . . . . . Subg. Ficus

\section{REFERENCES}

Berg, C.C. 1989. Classification and distribution of Ficus. In: Comparative biology of figs. Experientia 45: 605-611.

Berg, C.C. 1990. Reproduction and evolution in Ficus (Moraceae): Traits connected with the adequate rearing of pollinators. In: G.K. Gottsberger \& G.T. Prance (eds.), Reproductive biology and evolution of tropical woody Angiosperms. Mem. New York Bot. Garden 55: 169-185.

Berg, C.C. 1998. Phytogeography, systematics and diversification of African Moraceae compared with those of other tropical areas. In: C.R. Huxley, J.M. Lock \& D.F. Cutler (eds.), Chorology, taxonomy and ecology of the floras of Africa and Madagascar: 131-148. Kew.

Berg, C.C. \& J.T. Wiebes. 1992. African fig trees and fig wasps. Verh. Kon. Ned. Akad. Wet., afd. Natk., 2de reeks, 89: 1-298.

Corner, E.J.H. 1958. An introduction to the distribution of Ficus. Reinwardtia 4, 3: 15-45.

Corner, E.J.H. 1960a. Taxonomic notes on Ficus Linn., Asia and Australasia. I. Subgen. Urostigma (Gasp.) Miq. Gard. Bull. Singapore 17: 368-404.

Corner, E.J.H. 1960b. Taxonomic notes on Ficus Linn., Asia and Australasia. II. Subgen. Pharmacosycea Miq. Gard. Bull. Singapore 17: 405-415.

Corner, E.J.H. 1960c. Taxonomic notes on Ficus Linn., Asia and Australasia. III. Subgen. Ficus and sect. Ficus. Gard. Bull. Singapore 17: 416-441.

Corner, E.J.H. 1960d. Taxonomic notes on Ficus Linn., Asia and Australasia. IV. Subgen. Ficus sect. Sycidium. Gard. Bull. Singapore 17: 442-485.

Corner, E.J.H. 1960e. Taxonomic notes on Ficus Linn., Asia and Australasia. V. Subgen. Ficus sect. Rhizocladus, Kalosyce, Sinosycidium, Adenosperma, and Neomorphe. Gard. Bull. Singapore 18: $1-35$.

Corner, E.J.H. 1960f. Taxonomic notes on Ficus Linn., Asia and Australasia. VI. Subgen. Ficus sect. Sycocarpus Miq. Gard. Bull. Singapore 18: 36-69.

Corner, E.J.H. 1961. Taxonomic notes on Ficus Linn., Asia and Australasia. Addendum. Gard. Bull. Singapore 18: 83-97.

Corner, E.J.H. 1962a. The classification of Moraceae. Gard. Bull. Singapore 19: 187-252.

Corner, E.J.H. 1962b. Taxonomic notes on Ficus Linn., Asia and Australasia. Addendum II. Gard. Bull. Singapore 19: 385-401.

Corner, E.J.H. 1965. Check-list of Ficus in Asia and Australasia with keys to identification. Gard. Bull. Singapore 21: 1-186.

Corner, E.J.H. 1967. Ficus in the Solomon Islands and its bearing on the Post-Jurassic history of Melanesia. Philos. Trans., Ser. B, 253: 23-159.

Corner, E.J.H. 1969. The complex of Ficus deltoidea; a recent invasion of the Sunda Shelf. Philos. Trans., Ser. B, 256: 281-355.

Corner, E.J.H. 1970a. Ficus subg. Ficus. Two rare and primitive pachycaul species. Philos. Trans., Ser. B, 259: 353-381.

Corner, E.J.H. 1970b. New species of Streblus and Ficus (Moraceae). Blumea 18: 393-411.

Corner, E.J.H. 1972. New taxa of Ficus (Moraceae). Blumea 20: 427-432.

Corner, E.J.H. 1975. New taxa of Ficus (Moraceae) 2. Blumea 22: 299-309.

Daniels, J.D. \& R.O. Lawton. 1991. Habitat and host preferences of Ficus crassiuscula, a neotropical strangling fig of the lower-montane forest. J. Ecology 79: 129-141.

Gasparrini, G. 1844. Nova genera, quae supper nonnullis Fici specibus struebat. Napoli.

Gasparrini, G. 1845. Ricerche sulla natura del Caprifio, e del Ficus e sulla caprificazione. Napoli.

Go, R. 1998. A new species of Paratocarpus (Moraceae) from Sabah. Sandakania 12: 1-5. 
Herre, E.A., C.A. Machado, E. Bermingham, J.D. Nason, D.M. Windsor, S.S. McCafferty, W. van Houten \& K. Bachmann. 1996. Molecular phylogenies of figs and their pollinator wasps. J. Biogeogr. 23: 521-530.

King, G. 1887. The species of Ficus of the Indo-Malayan and Chinese countries. Ann. Roy. Bot. Gard. (Calcutta) 1, 1: 1-66, t. 1-87.

Kochummen, K.M. 1998. New species and varieties of Moraceae from Malaysia. Gard. Bull. Singapore 50: 197-219.

Laman, T.G. \& G.D. Weiblen. 1998. Figs of Gunung Palung National Park (West Kalimantan, Indonesia). Trop. Biodiversity 5, 3: 245-297.

Mildbraed, J. \& M. Burret. 1912. Die afrikanischen Arten der Gattung Ficus Linn. Bot. Jahrb. Syst. 46: $175-269$.

Miquel, F.A.W. 1844. Fragmenta phytographica. Ann. Sci. Nat. Bot., Sér. 3, 1: 31-41.

Miquel, F.A.W. 1847. Prodromus monographiae Ficuum. London J. Bot. 6: 514-588.

Miquel, F.A.W. 1848. Prodromus monographiae Ficuum. London J. Bot. 7: 64-78, 109-116, 221-236, 425-471.

Miquel, F.A.W. 1867. Annotationes de Ficus speciebus. Ann. Mus. Lugd.-Bat. 3: 260-315. Leiden.

Prósperi, J. 1998. Biologie du dévellopement des hémi-épiphytes ligneux. Thesis University of Montpellier II, France.

Ramirez, B.W. 1977. A new classification of Ficus. Ann. Missouri Bot. Gard. 64: 296-310.

Thunberg, C.P. 1786. Ficus. Uppsala.

Vahl, M.H. 1805. Enum. Pl. 2. Copenhagen.

Weiblen, G.D. 2000. Phylogenetic relationships of functionally dioecious Ficus (Moraceae) based on ribosomal DNA sequences and morphology. Amer. J. Bot. 87: 1342-1357.

Wiebes, J.T. 1992. Fig wasps. In: C.C. Berg \& J.T. Wiebes, African fig trees and fig wasps. Verh. Kon. Ned. Akad. Wet., afd. Natk., 2de reeks, 89: 1-298.

Wiebes, J.T. 1994. The Indo-Australian Agaoninae (pollinators of figs). Verh. Kon. Ned. Akad. Wet., afd. Natk., 2de reeks, 92: 1-208.

Wiebes, J.T. 1995. The New World Agaoninae (pollinators of figs). Verh. Kon. Ned. Akad. Wet., afd. Natk., 2de reeks, 94: 1-60. 